\title{
Article \\ Studying the Effect of Chondroitin Sulfate on the Physicochemical Properties of Novel Gelatin/Chitosan Biopolymer-Based Cryogels
}

\author{
Gulshakhar Kudaibergen ${ }^{1, *}\left(\mathbb{D}\right.$, , Madina Zhunussova ${ }^{1} \mathbb{D}$, Ellina A. Mun ${ }^{2} \mathbb{C}$, Anar Arinova $^{3}$ \\ and Vyacheslav Ogay ${ }^{1} \mathbb{C}$ \\ 1 Stem Cell Laboratory, National Center for Biotechnology, Nur-Sultan 010000, Kazakhstan; \\ zhunussova@biocenter.kz (M.Z.); ogay@biocenter.kz (V.O.) \\ 2 School of Science and Humanities, Nazarbayev University, Nur-Sultan 010000, Kazakhstan; \\ ellina.mun@nu.edu.kz \\ 3 National Laboratory Astana, Nazarbayev University, Nur-Sultan 010000, Kazakhstan; arinova.777@mail.ru \\ * Correspondence: kudaibergen@biocenter.kz
}

\section{check for}

updates

Citation: Kudaibergen, G.;

Zhunussova, M.; Mun, E.A.; Arinova,

A.; Ogay, V. Studying the Effect of

Chondroitin Sulfate on the

Physicochemical Properties of Novel

Gelatin/Chitosan Biopolymer-Based

Cryogels. Appl. Sci. 2021, 11, 10056.

https://doi.org/10.3390/

app112110056

Academic Editors: Timothy E.

L. Douglas and Katarzyna Klimek

Received: 11 October 2021

Accepted: 26 October 2021

Published: 27 October 202

Publisher's Note: MDPI stays neutral with regard to jurisdictional claims in published maps and institutional affiliations.

Copyright: (c) 2021 by the authors. Licensee MDPI, Basel, Switzerland This article is an open access article distributed under the terms and conditions of the Creative Commons Attribution (CC BY) license (https:// creativecommons.org/licenses/by/ $4.0 /)$.

\begin{abstract}
The application of biopolymers in tissue engineering is of a great interest due to of their inherent properties such as cell adhesion, biodegradation, bioavailability, and viscoelasticity. In this study, we synthesized cryogels based on biopolymers of gelatin, chitosan, and chondroitin sulfate by cryopolymerization and studied the effect of chondroitin sulfate on changing the physicochemical properties of cryogels such as pore size, pore volume, density, gel fraction, and biodegradation. A macroporous surface of the synthesized polymers has been investigated by SEM. The glass transition temperatures of the crosslinked cryogels, determined by the DSC method, were higher compared to that of the non-crosslinked cryogel used as a reference. The results of the MTT test showed that aqueous extracts of the prepared cryogels had no toxic effect on rat adipose-derived mesenchymal stem cells. The research in this area is of great importance and provides new insights into novel, effective methods for obtaining biopolymers that can be used as carriers of cells.
\end{abstract}

Keywords: cryogels; gelatin; chitosan; chondroitin sulfate; biopolymers; cells

\section{Introduction}

Developments in the field of tissue engineering give impetus to the creation of new biomaterials that can be used to repair damaged tissues such as bone, muscle, skin, cartilage, the liver, and the heart [1-3]. Biopolymers used for tissue engineering should comply with the following requirements: high biodegradability, non-toxicity, porosity for cell attachment and proliferation, mechanical resistance to the pressure created by tissue, and the ability to mimic the damaged tissue $[4,5]$.

Biomaterials can be synthesized using various techniques, such as electrospinning and 3D printing. Among those, cryopolymerization is a unique method and has several advantages over other methods. A porous structure can be produced by cryo-freezing with the controllable size and volume of the pores that can be adjusted by changing the temperature and the concentration of the starting monomers or prepolymers. The advantage of using cryogels over conventional nano/mesoporous hydrogels is their welldeveloped 3D porous structure, consisting mainly of open pores, which can be used as a scaffold and carrier of cells [6-10].

The synthesis of materials at low temperatures provides cryogels with large pores (up to $200 \mu \mathrm{m}$ ) with a spongy and elastic morphology [6-9]. The stage of cryogel polymerization occurs through two main mechanisms: chemical or physical [7-9,11,12]. Chemically crosslinked cryogels can be obtained by covalent crosslinking of monomers or prepolymers with the aid of crosslinking agents $[13,14]$. These bonds have a higher binding energy 
and, therefore, provide better stability of the chemical interaction between polymer macromolecules due to crosslinking agents $[15,16]$. Physically crosslinked cryogels are formed due to ionic/hydrophobic interactions between polymer chains, creating polyelectrolyte complexes (PECs) [3,8,17-21].

Synthetic and natural polymers are used as polymers for tissue engineering. Synthetic polymers such as poly (lactic acid) (PLA), poly (lactic-co-glycolide) (PLGA), poly ( $\varepsilon$-caprolactone) (PCL), and polyethylene glycol (PEG) are widely used as carriers for peptides, drugs, genes, proteins, and so on due to high mechanical strength and biocompatibility [22-24]. Natural polymers, due to the presence of certain segments that contribute to an additional therapeutic effect during tissue regeneration, are also widely employed for biomedical applications. Due to their superior biocompatibility, negative immunological influence, elastic and diffusive properties, and low toxicity, natural polymers such as collagen, chitosan, alginate, silk, fucoidan, elastin, gelatin, and hyaluronic acid are extensively used in tissue engineering [25-28].

Gelatin (Gel) is a biopolymer derived from animal collagen. It is a cheap, biocompatible, biodegradable, non-immunogenic biopolymer widely used in clinical applications [29]. In terms of chemical composition, gelatin is close to collagen. However, unlike collagen, gelatin, whose macromolecules do not have an ordered structure, is soluble in water, which makes it a convenient material for the preparation of initial gel-forming systems for the formation of cryogels or cryostructures [30,31].

Chitosan (Ch), a naturally occurring unsulfated glycosaminoglycan (GAG), is a linear polysaccharide that is a part of the extracellular matrix $(\mathrm{ECM})$, consisting of $\beta(1 \rightarrow 4)$ linked D-glucosamine residues with a variable number of randomly located n-acetyl-glucosamine groups [32,33]. Chitosan (Ch) has excellent biocompatibility, biodegradability, non-toxicity, adsorptive properties, and degradability by lysozyme, a natural enzyme [34].

Chondroitin sulfate (CS) is a sulfated polysaccharide in $\mathrm{C} 4$ or $\mathrm{C} 6$ of its repeating unit, containing GAG and galactosamine [35]. CS attaches to proteins as part of proteoglycan, an important component of cartilage, and its inclusion in a scaffold allows for the secretion of proteoglycans and type II collagen [36]. Due to its physicochemical, mechanical, and biological properties, CS is used as a polymer network for tissue engineering [37-39].

Obtaining cryogels based on biopolymers containing polysaccharide and polypeptide residues make it possible to impart desired properties to polymers, such as cell adhesion and degradability [10]. To date, there are works on the synthesis of cryogels based on gelatin, chondroitin-6-sulfate, and chitosan using crosslinker, gelatinization and modification agents [39-42]. It is known that cryogels containing mainly glycosaminoglycans (GAG), or composites of GAGs and other natural or synthetic polymers, have a number of advantages since they correspond to the native extracellular matrix (ECM) [36,43-45]. Such cryogels have a macroporous structure, strength, mechanical resistance, and they can be used in regenerative medicine, mainly as a polymeric matrix for the delivery of drugs and cells to the damaged tissues. The purpose of this investigation is to study the effect of CS on the physical and chemical properties of Gel/Ch-based cryogels. Cryopolymerization enables the synthesis of macroporous structural cryogels with large pore size compared to hydrogels. The novelty of this work lies in the preparation of macroporous cryopolymers based on Gel, Ch, and CS containing GAGs. Cryogels were obtained in two stages: initially, by preparing PECs and then by chemically crosslinking them using a carbimide such as $\mathrm{N}$-(3-dimethylaminopropyl)-N-ethylcarbodiimide hydrochloride (EDC). To determine the optimal concentration of CS in Gel/Ch cryogels, the properties of polymers were studied using FTIR, SEM, TG/DTA/DSC, degradation experiments, and swelling tests, and the potential of cryogels as a matrix for tissue engineering were determined through MTT assay. 


\section{Materials and Methods}

\subsection{Materials}

Gelatin (Type A), chitosan (low molecular weight, 75-85\% deacetylated), acetic acid (ReagentPlus, $99 \%$ pure), sodium hydroxide powder $(\mathrm{NaOH}$, analytical grade, $99 \%$ pure), phosphate buffered saline (PBS, pH 7.4), N-(3-dimethylaminopropyl)-N-ethylcarbodiimide hydrochloride (EDC), and Dulbecco's Modified Eagle medium (DMEM) were all purchased from Sigma-Aldrich and used without purification. Chondroitin sulfate A sodium salt was purchased from Glentham Life Sciences, Ltd. MilliQ water $(18.2 \mathrm{M} \Omega \mathrm{cm})$ was used for the preparation of all aqueous solutions.

\subsection{Preparation of the Cryogels}

The cryogels were prepared in an aqueous $1 \%(v / v)$ acetic acid solution of $\mathrm{Gel}, \mathrm{Ch}$, and CS using EDC as a crosslinker. The synthetic strategy consists of two steps, namely (i) the preparation of physically crosslinked cryogels via ionic interactions, and (ii) their chemical crosslinking using the EDC crosslinker. In the preliminary experiments, the concentration ratio of gelatin to chitosan in the reaction solution was varied to obtain mechanically stable physical cryogels that do not lose their shape upon repeated washing (data not shown). The ideal concentrations to form water-stable physically crosslinked cryogels were 0.4 and $0.2 \%(w / v)$ for Gel and Ch, respectively. They were fixed in our experiments, while CS concentration was varied between 0.01 and $0.25 \%(w / v)$ (Table 1$)$. Typically, to prepare cryogels with $0.01 \%(w / v)$ CS, Gel $(40 \mathrm{mg})$, and CS $(20 \mathrm{mg})$ were dissolved in $10 \mathrm{~mL}$ of acetic acid solution on a mechanical rotor at $37^{\circ} \mathrm{C}$ overnight. The acidity of the solution was then adjusted using $1 \mathrm{M}$ of $\mathrm{NaOH}$ to $\mathrm{pH}=5$ to protonate amine groups of $\mathrm{Ch}$. After the addition of CS (10-250 mg), the solution was transferred in syringes and incubated at $-12{ }^{\circ} \mathrm{C}$ for $24 \mathrm{~h}$. After thawing at room temperature, the physically crosslinked polymers thus formed were washed with MilliQ water and PBS $(\mathrm{pH}=7.4)$ to neutralize the residual acetic acid. They were then frozen at $-70{ }^{\circ} \mathrm{C}$ and lyophilized using a Martin Christ Beta 2-8 LDplus freeze dryer. Disks of $2 \mathrm{~mm}$ in thickness and $10 \mathrm{~mm}$ in diameter were cut from the cryogels with a sharp blade. Freeze dried cryogels in the form of disks were then chemically crosslinked using $1 \%$ EDC in ethanol solution for $16 \mathrm{~h}$. They were washed three times with MilliQ water to remove residual EDC and freeze-dried. The cryogels were denoted as GelChCSx, where $\mathrm{x}$ is the amount of $\mathrm{CS}$, in milligrams, in a $10 \mathrm{~mL}$ reaction solution.

Table 1. Synthetic parameters, gel fraction, density, pore volume, and surface area of the cryogels.

\begin{tabular}{ccccc}
\hline Samples & Gel:Ch:CS (mg) & Gel (\%) & $\rho(\mathbf{g} / \mathbf{m L})$ & $\begin{array}{c}\text { Pore Volume } \\
\text { (\%) }\end{array}$ \\
\hline GelChCS10 & $400: 200: 10$ & $74 \pm 1$ & $0.074 \pm 0.006$ & $86 \pm 2$ \\
\hline GelChCS25 & $400: 200: 25$ & $76 \pm 2$ & $0.080 \pm 0.008$ & $86 \pm 2$ \\
\hline GelChCS50 & $400: 200: 50$ & $82 \pm 1$ & $0.081 \pm 0.006$ & $89 \pm 2$ \\
\hline GelChCS100 & $400: 200: 100$ & $80 \pm 2$ & $0.085 \pm 0.004$ & $84 \pm 1$ \\
\hline GelChCS250 & $400: 200: 250$ & $61 \pm 1$ & $0.126 \pm 0.019$ & $78 \pm 2$ \\
\hline
\end{tabular}

\subsection{Gel Fraction Analysis}

The Gel fraction of the cryogels was determined using a gravimetric method. The cryogel specimens were immersed in an excess of deionized water for $48 \mathrm{~h}$ at room temperature during which water was refreshed twice to extract the soluble species. After freeze-drying, the gel fraction was estimated by [46]:

$$
\operatorname{Gel}(\%)=\frac{W_{w}}{W_{i}} \times 100
$$

where $W_{w}$ and $W_{i}$ are the masses of the specimens after and before extraction with water. 


\subsection{Swelling Behavior}

The swelling degree of cryogels was measured using a gravimetric procedure $[47,48]$. The dry cryogel specimens of a mass around $50 \mathrm{mg}\left(\mathrm{W}_{\mathrm{d}}\right)$ were incubated in $0.1 \mathrm{M}$ of PBS ( $\mathrm{pH} 7.4)$, and their swollen masses $\left(\mathrm{W}_{\mathrm{s}}\right)$ were recorded after $24 \mathrm{~h}$. All the samples were taken in triplets to reduce any errors. The swelling ratio (SR) of the cryogels was calculated by:

$$
\mathrm{SR}(\%)=\frac{\mathrm{W}_{\mathrm{s}}-\mathrm{W}_{\mathrm{d}}}{\mathrm{W}_{\mathrm{d}}}
$$

\subsection{In Vitro Degradation}

Cryogels were weighed $\left(\mathrm{W}_{1}\right)$ and transferred to $50 \mathrm{~mL}$ tubes filled with $0.1 \mathrm{M}$ of sterile PBS (pH 7.4). The tubes were incubated at $37^{\circ} \mathrm{C}$ for 8 weeks during which the solution was refreshed twice in a week. At predetermined times, cryogel samples were taken from the solution and washed with deionized water after freeze-drying overnight and weighing $\left(\mathrm{W}_{2}\right)$. The degree of degradation (DD) was determined using the following equation [49]:

$$
\mathrm{DD}(\%)=\frac{\mathrm{W}_{1}-\mathrm{W}_{2}}{\mathrm{~W}_{1}} \times 100
$$

\subsection{Density and Pore Volume of Cryogels}

The density of the cryogels was evaluated from the mass-to-volume ratio of the dry cryogels. The apparent density $(\rho)$ was estimated as [50]:

$$
\rho=\frac{W}{\pi \times(D / 2)^{2} \times H}
$$

where $\mathrm{W}, \mathrm{D}$, and $\mathrm{H}$ are the mass, diameter, and thickness of the dry cryogels.

The pore volume of the cryogels was estimated from the uptake of ethanol into the pores. Ethanol is a non-solvent for the cryogels, and it easily penetrates into the pores. The measurements were conducted by immersing dry cryogel specimens with a mass of $W_{D}$ into absolute ethanol for $1 \mathrm{~h}$ and then recording their final mass $\mathrm{W}_{\mathrm{S}}$. The pore volume (PV) was estimated as [51]:

$$
\mathrm{PV}(\%)=\frac{\left(\mathrm{W}_{\mathrm{S}}-\mathrm{W}_{\mathrm{D}}\right)}{\mathrm{W}_{\mathrm{S}}} \times 100
$$

\subsection{Culture of Rat Adipose-Derived MSC}

In this study, outbred male Wistar rats weighing 280-330 g were used, purchased from the Pushchino Laboratory Animal Nursery (Russia). The animals were kept in a vivarium, including a 12 -h day/night cycle, at a temperature of $22-23^{\circ} \mathrm{C}$. This study was conducted according to the guidelines of the Declaration of Helsinki and approved by the Local Ethics Committee of the National Center for Biotechnology (number NCB-04-2020). The adipose tissue was isolated from the kidney area, washed of blood with PBS, and cut into small pieces with a scalpel. Next, the adipose tissue was digested in a $0.25 \%$ collagenase type I solution for $1 \mathrm{~h}$ at $37^{\circ} \mathrm{C}$. Afterwards, the cell suspension was filtered through a cell strainer and suspended in Dulbecco's Modified Eagle's Medium (DMEM, Sigma, Saint Louis, MO, USA) supplemented with 10\% fetal bovine serum (FBS, Gibco, Paisley, UK) and $1 \%$ penicillin/streptomycin. Then, the cells were incubated in a $5 \%$ humidified $\mathrm{CO}_{2}$ chamber at $37^{\circ} \mathrm{C}$. When the cells reached $80 \%$ confluence, they were trypsinized with $0.25 \%$ trypsin for $1 \mathrm{~min}$ at $37^{\circ} \mathrm{C}$. Cells were passed once per week, and the third passages of ADMSC were seeded on scaffolds at a density of $5 \times 10^{5}$ cells $/ \mathrm{mL}$. Then, they were cultured in an incubator at $37^{\circ} \mathrm{C}$ and $5 \%$ humidified $\mathrm{CO}_{2}$.

\subsection{MTT Assay}

The cytotoxicity of the aqueous extracts from the cryogel samples on the viability of rat ADMSC was assessed with an MTT assay. The aqueous extracts were obtained after 
the incubation of the cryogel samples $(1 \mathrm{mg})$ in basal culture media alpha-MEM $(1 \mathrm{~mL})$ at $37^{\circ} \mathrm{C}$ for $24 \mathrm{~h}$. Rat ADMSC were seeded at a density of $5 \times 10^{3}$ cells per well in 96-well plates and incubated at $37^{\circ} \mathrm{C}$ and $5 \% \mathrm{CO}_{2}$. After $16 \mathrm{~h}$, the culture medium (alpha-MEM supplemented with $10 \% \mathrm{FBS}$ ) was replaced by an experimental one with different dilutions of extract, ranging from 0.78 to $100 \%$, in triplicate, and reincubated for $24 \mathrm{~h}$ at $37^{\circ} \mathrm{C}$ and $5 \%$ $\mathrm{CO}_{2}$. Culture medium without extract served as a control in this assay. After removing culture supernatants, the resulting purple formazan crystals were dissolved in $200 \mu \mathrm{L}$ of dimethyl sulfoxide. Optical density was measured at a wavelength of $580 \mathrm{~nm}$ using a microplate reader (Bio-Rad 680, California City, CA, USA). Cell viability values were calculated by the formula Atest/Acontrol $\times 100$, where Atest is the optical density of the test wells, Acontrol is the optical density of thecontrol wells, and 100 is $100 \%$ value.

\subsection{Characterization}

Fourier transform infrared (FTIR) spectra of the samples in a dried state were recorded on a Thermo Scientific Nicolet iS10 FTIR spectrometer in the wavelength range of 4000-400 $\mathrm{cm}^{-1}$.

The morphology of the dried cryogels was observed using a scanning electron microscope (SEM, Auriga Crossbeam 540, Carl Zeiss, Oberkochen, Germany) after coating with gold. The average diameter of the pores was measured using the image-processing tools of the ImageJ software.

The thermal behavior of the cryogels was analyzed by thermogravimetry (TG), differential thermogravimetry (DTG), and differential scanning calorimetry (DSC) using a Simultaneous Thermal Analyzer STA 6000 (PerkinElmer, Waltham, MA, USA) under a nitrogen atmosphere at a heating rate of $10^{\circ} \mathrm{C} / \mathrm{min}$ in the range +30 to $950{ }^{\circ} \mathrm{C}$.

\subsection{Statistical Analysis}

The obtained data were analyzed using the statistical software Origin 8.1. and GraphPad Prism. Student's $t$-test was used to analyze the significant difference between two groups, and the difference among multiple groups was determined according to one-way ANOVA (Tukey's posttest). A $p$ value $\leq 0.05$ was considered statistically significant. Results are given as mean $\pm \mathrm{SD}$.

\section{Results and Discussion}

It is known that Ch contains amine groups and exhibits typical polyelectrolyte properties [52], while Gel is a polyampholyte containing negative carboxyl and positive amine groups [29]. The third component of the cryogels, namely CS, is an anionic polysaccharide containing sulfo groups [24]. Thus, the formation of a water-stable cryogel with a 3D macroporous structure was due to the ionic interactions of carboxyl and amine groups of $\mathrm{Gel}$, amine groups of $\mathrm{Ch}$, and the sulfo group of CS. The so-formed physical cryogels were further crosslinked using the chemical crosslinker EDS to produce dual crosslinked cryogels (Figure 1).

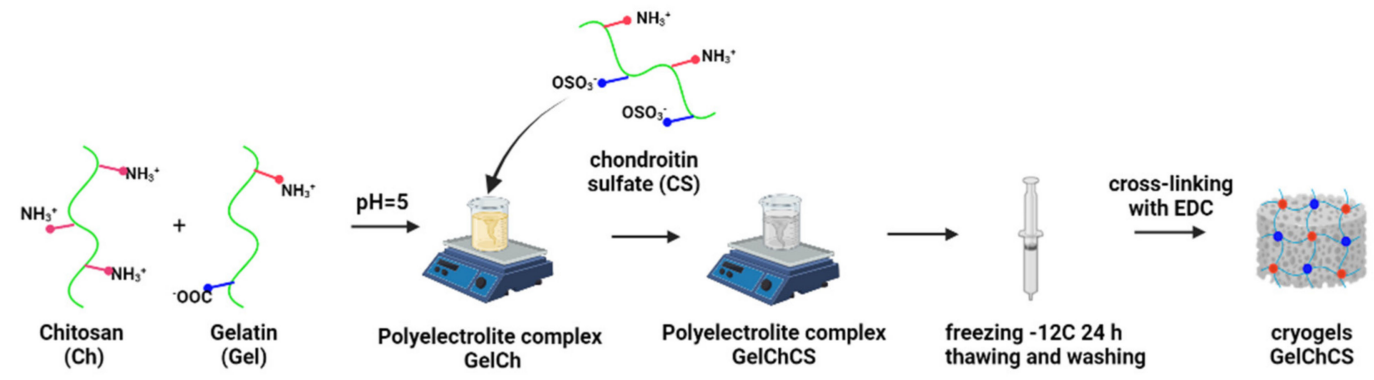

Figure 1. Scheme showing the formation of the cryogels.

The presence of the functional groups in the cryogels is confirmed by FTIR measurements (Figure 2). To confirm the effect of the EDC crosslinker, a control sample without chemical crosslinking was also measured. The spectra show a band in the range 
$3000-3600 \mathrm{~cm}^{-1}$, which is related to the stretching vibrations of the $\mathrm{O}-\mathrm{H}$ and $\mathrm{N}-\mathrm{H}$ functional groups (amide A) involved in the intramolecular hydrogen bond between chitosan and gelatin molecules. The bands at $3000-3500 \mathrm{~cm}^{-1}$ are due to several symmetric and asymmetric stretching vibrations of $\mathrm{C}-\mathrm{H}$. Bands at $1636 \mathrm{~cm}^{-1}$ refer to $\mathrm{CO}-$ and $\mathrm{CN}$-amide I. The bands at $1544 \mathrm{~cm}^{-1}$ refer to the deformation vibrations of $\mathrm{NH}$ groups and the stretching vibrations of $\mathrm{CN}$ groups (amide II). The absorption of the spectrum in the $1250 \mathrm{~cm}^{-1}$ range belongs to the stretching vibrations of $\mathrm{CN}$ groups (amide III). The main peaks corresponding to amide I, amide II, and amide III are characteristic of $\mathrm{Gel}, \mathrm{Ch}$, and CS. The band at $1019 \mathrm{~cm}^{-1}$ is due to the stretching vibrations of $\mathrm{C}-\mathrm{O}$ groups. The shift of the peaks in the region of 1406 and $1636 \mathrm{~cm}^{-1}$ in the control sample without chemical crosslinking relative to those of the cryogels indicates the formation of hydrogen bonds between $\mathrm{Ch}$ and Gel. Comparing the spectra of cryogels with and without EDC, one can notice the disappearance of the peak in cryogels (GelChCS10-GelChCS250) in the region of 1406 and a shift of the peak at $1636 \mathrm{~cm}^{-1}$, indicating the formation of a bond between chitosan and gelatin, while the disappearance of the peak at $1340 \mathrm{~cm}^{-1}$ indicates the formation of $\mathrm{CONH}_{2}$ (CS crosslinking with chitosan), which confirms the formation of crosslinked cryogels.

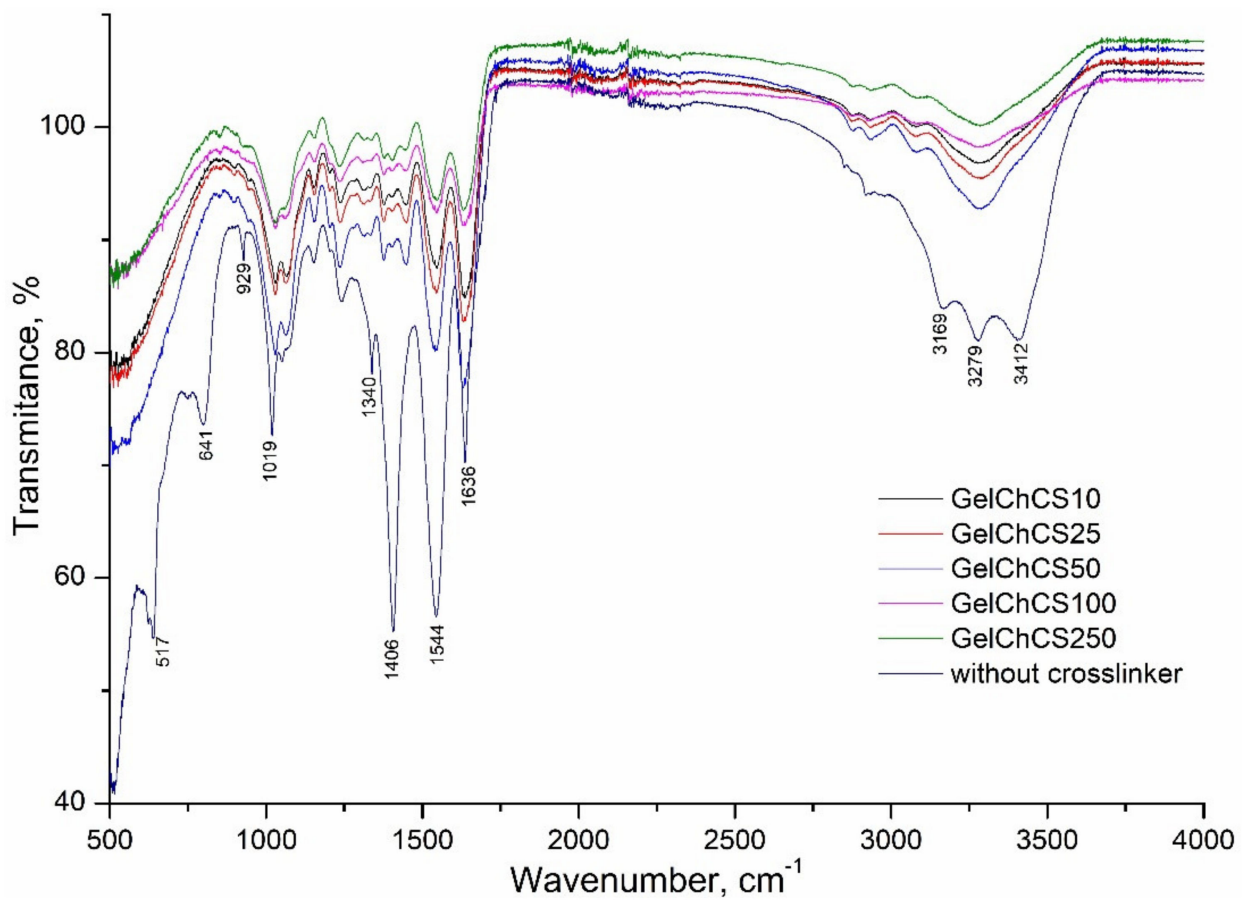

Figure 2. FTIR spectra of GelChCS cryogels.

To determine the efficiency of chemical crosslinking, the gel content of the cryogels was determined as it affects their physicochemical properties (Table 1). For the GelChCS50 and GelChCS100 cryogels, the gel fraction was maximum, i.e., $82 \pm 1 \%$ and $80 \pm 2 \%$, respectively. This can be caused by the formation of a stable crosslinked polymer network, in which the sol (soluble part) fraction is present to a lesser extent. This may also be due to the hydrophilic properties of gelatin and the non-dense polymer structure for the rest of the samples.

When the cryogels thaw after preparation, macropores are formed in the place of ice crystals while the crosslinked polymer chains act as the pore walls, providing a large surface area for cell attachment and proliferation. Moreover, the more porous the polymer, the better it is for the penetration of fluids and cells. Table 1 shows the density, porosity, and surface area of the cryogels formed at various CS contents. The general trend is that, as the CS concentration increased, the density of the scaffolds also increased while their porosity slightly decreased. Decreasing the pore volume of the scaffolds with increasing CS content could be attributed to the decrease of the freezing temperature of the reaction 
system reducing the amount of ice crystals and hence, the pores. Table 1 shows that all the cryogels had pore volumes around $80 \%$, and hence they are ideal for use in tissue engineering [47]. Based on the results obtained, it can be concluded that the cryogels have rather favorable properties for their use as a carrier and for cell proliferation.

The swelling capacity of polymers is inherent in biomedical applications and tissue engineering. The swelling capacity of polymers makes it possible to use them in drug delivery systems [53]. The equilibrium swelling ratio of the cryogels was determined in PBS (pH 7.4) at $37^{\circ} \mathrm{C}$ after an immersion time of $24 \mathrm{~h}$, while at longer times, they started to biodegrade. The results showed that the samples GelChCS10, GelChCS25, and GelChCS50 had the highest swelling ratios of around 12 as compared to other cryogels (the data points at time $=1 \mathrm{~h}$ in Figure 3). Apparently, with increasing CS concentration, more porous polymer networks are formed, which provide the greatest swelling ability. However, the GelChCS10 and GelChCS25 cryogels were less stable and degraded over time. The cryogels GelChCS100 and GelChCS250 ha closed and large pore morphologies (SEM results are shown below), which cannot swell like previous cryogels.

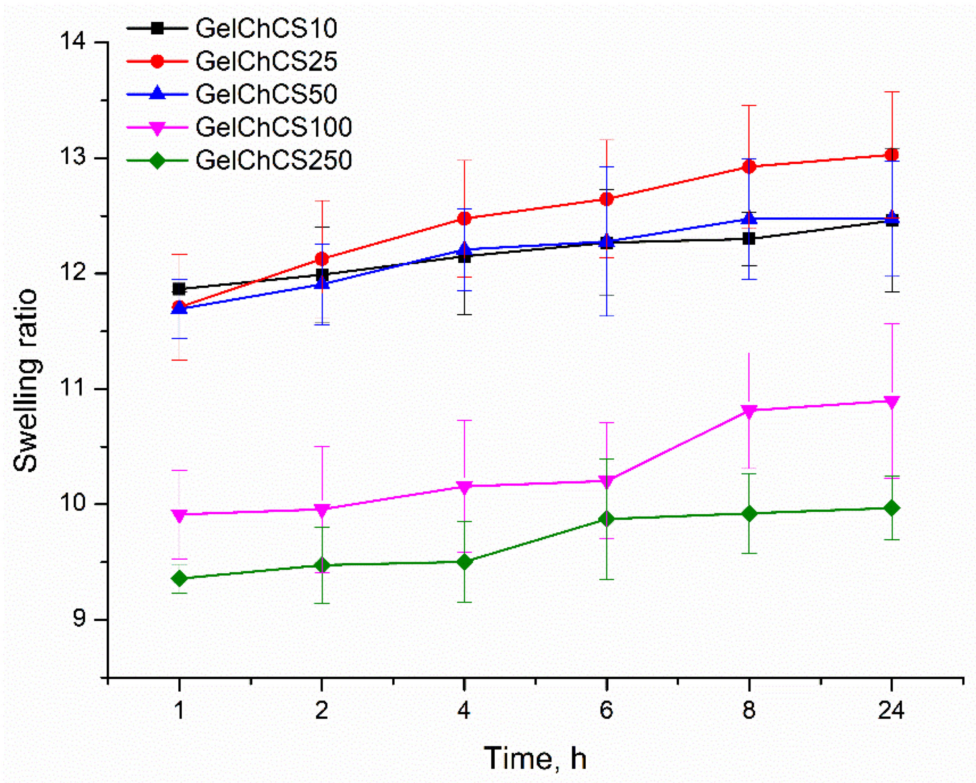

Figure 3. Dependence of the swelling capacity of the cryogels in PBS at $37^{\circ} \mathrm{C}$ at the time of swelling.

The biodegradation of polymers also plays an important role in their use in tissue engineering. Partial degradation makes it possible to use the polymer for a longer time as a carrier of cells without additional implantation of the biomaterial into the studied healing site. The lower the degree of biodegradation, the longer the period of time the polymer can be used to deliver a biological object, such as drugs and cells. Thus, we investigated the degradation of the cryogel matrices GelChCS10, GelChCS25, GelChCS50, GelChCS100, and GelChCS250 in a sterile solution of $0.1 \mathrm{M}$ of PBS (pH 7.4) at $37{ }^{\circ} \mathrm{C}$ under sterile conditions for 8 weeks. The in vitro decomposition rate of the cryogels was $58 \pm 2.5,55 \pm 3.5,40 \pm 2.1,43 \pm 2.5$, and $81 \pm 1.6 \%$ for GelChCS10, GelChCS25, GelChCS50, GelChCS100, and GelChCS250, respectively (Figure 4).

During biodegradation, polymer chains forming the pore walls of the cryogels break down into low-molecular weight polymers, and thereby they dissolve in the solvent and lead to weight loss. The presence of water-soluble gelatin in the present cryogels provided an additional hydrophilicity and enhances biodegradation. As seen from Figure 4, GelChCS50 and GelChCS100 cryogels had the lowest degree of degradation which is likely due to the larger number of covalent bonds between $\mathrm{Gel}, \mathrm{Ch}$, and CS via the EDC crosslinker. In contrast, the GelChCS250 sample lost its shape after a week in PBS and exhibited the maximum degree of degradation. Apparently, the excessive amount of CS anionic groups does not create conditions for covalent crosslinking with EDC so that weakly crosslinked 
polymer chains are formed, thereby destroying intermolecular chains inside the cryogel. It is assumed that with an excess of CS, a large number of unreacted chains is formed, which makes the cryogel unstable. On week 6, visual observation showed that the GelChCS10 and GelChCS25 samples had also lost their original shapes. These results suggest that weakly crosslinked polymer chains are formed in the samples, which are unable to withstand the effect of PBS ( $\mathrm{pH}$ 7.4) at long times. An increased biodegradation of polymers with increasing CS concentration was also reported in the literature [24].

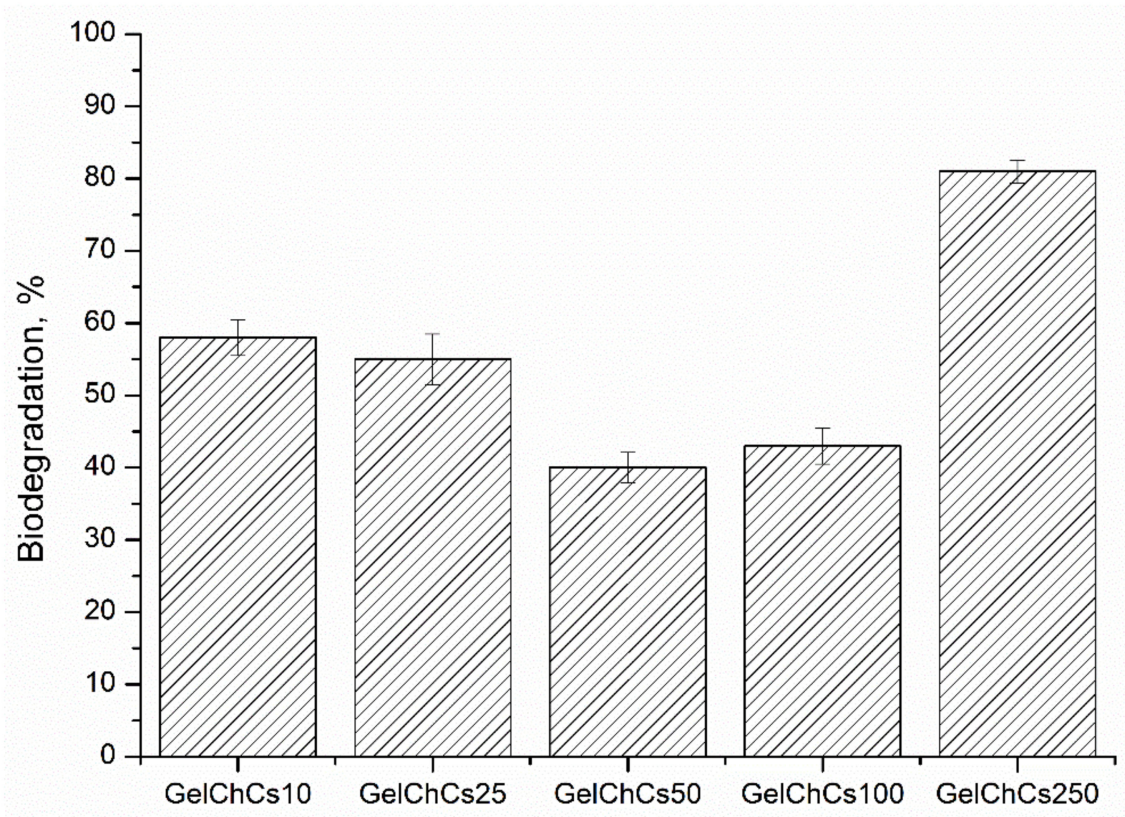

Figure 4. Biodegradation behavior of the cryogels in PBS at $37^{\circ} \mathrm{C}$ for 8 weeks.

Pore size and shape play an important role in tissue engineering scaffolds. The pores provide intercellular contact between cells, showing higher markers of chondrogenesis, and can be used for the treatment of bone regeneration and in tissue engineering in general. It is known that pores above $500 \mu \mathrm{m}$ are the limit for scaffolds, since at a given size, cell infiltration is enhanced instead of promoting cell adhesion to the scaffold $[54,55]$.

The surface morphology of the synthesized polymers was examined by SEM analysis (Figure S1). All the cryogels exhibited a macroporous structure consisting of pores having different shapes and sizes. The average pore sizes of the cryogels significantly changed depending on the CS concentration. For instance, they were $123 \pm 75,174 \pm 68,230 \pm 76$, $217 \pm 124$, and $185 \pm 83 \mu \mathrm{m}$ for GelChCS10, GelChCS25, GelChCS50, GelChCS100, and GelChCS250, respectively. The GelChCS100 sample had pores above $500 \mu \mathrm{m}$, which does not allow MSC cells to proliferate directly onto the polymer, since the cells may not attach to the cryogel. The GelChCS50 and GelChCS100 samples had sufficient pores. The pores on the surface of the GelChCS50 cryogel were evenly distributed and may be sufficient for chondrogenic differentiation, since the largest pore size accommodates more cells that can agglomerate.

The TG/DTA results of the scaffolds together with the control scaffold without chemical crosslinking are shown in Figure 5. TG curves show the weight loss of the samples in the temperature ranges of $30-100{ }^{\circ} \mathrm{C}$ and $200-500{ }^{\circ} \mathrm{C}$. The weight loss at low temperature $\left(<100{ }^{\circ} \mathrm{C}\right)$ is due to the loss of water in the samples. It is known that at $40-60{ }^{\circ} \mathrm{C}$ and $80-120^{\circ} \mathrm{C}$, free water and water bound with hydrogen bonds are released, respectively [47]. At higher temperatures until $160^{\circ} \mathrm{C}$, water molecules more strongly linked through polar interactions with carboxylate groups are released [42]. At the high temperature range $\left(200-500{ }^{\circ} \mathrm{C}\right)$, an average weight loss of $60 \%$ of the substance occurred, which corresponds to the thermal and oxidative decomposition of the cryogel components. The decomposition of the control sample occurred at $110{ }^{\circ} \mathrm{C}$, reaching a maximum at $270{ }^{\circ} \mathrm{C}$, while in 
other cryogels, decomposition occurred on average from $200{ }^{\circ} \mathrm{C}$ and decomposed to the maximum at $280-311^{\circ} \mathrm{C}$; this confirms the formation of chemical crosslinks between the functional groups of gelatin, chitosan, and chondroitin sulfate with EDC. Upon reaching the final temperature, the weight losses became $80,78,79,81$, and $82 \%$ for GelChCS10, GelChCS25, GelChCS50, GelChCS100, and GelChCS250, respectively, as compared to 95\% for the control sample.

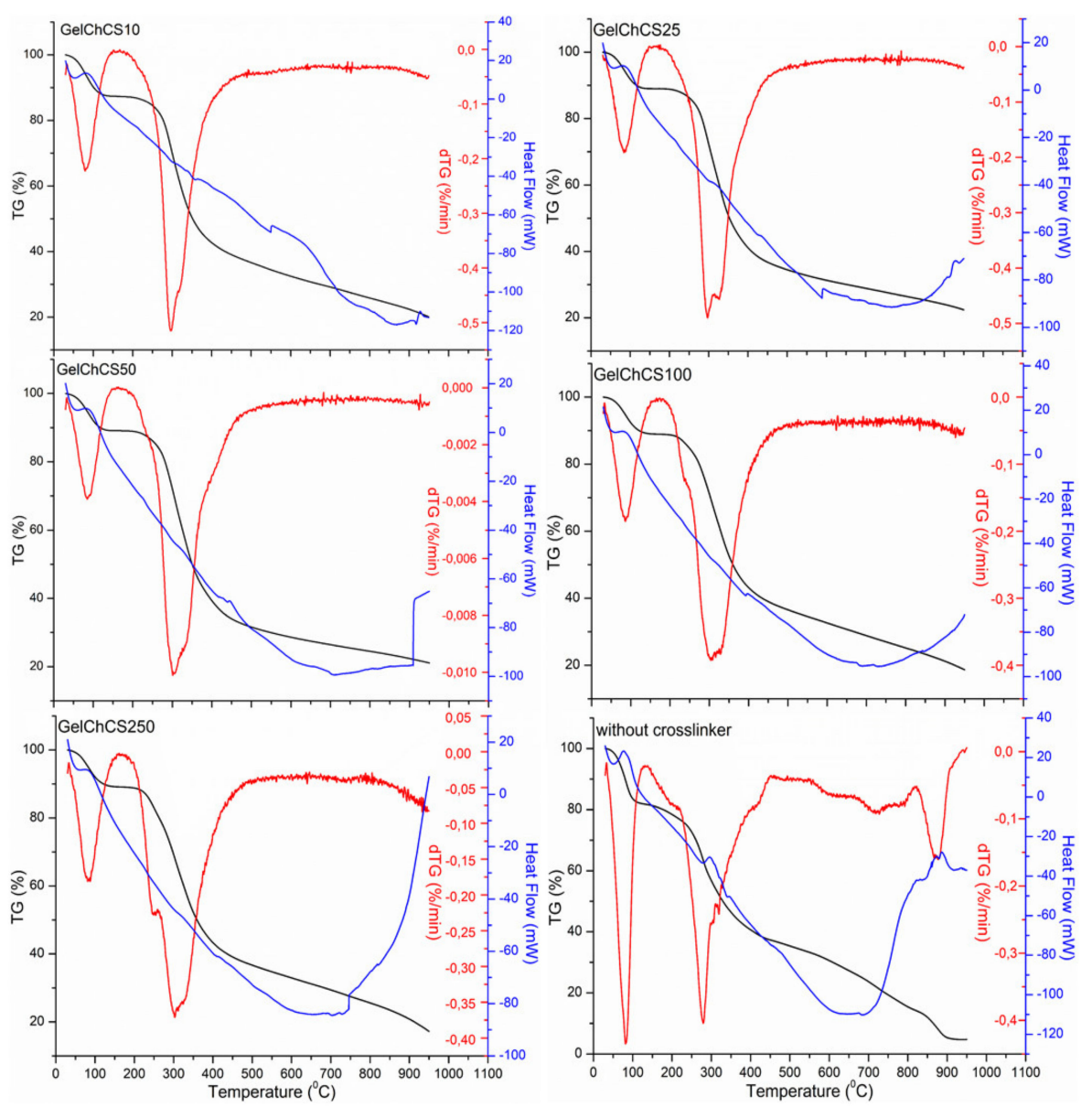

Figure 5. TG/DTG/DSC curves of the cryogels.

The DSC thermograms of the cryogels show an endothermic peak up to $100{ }^{\circ} \mathrm{C}$ that is seen for all cryogels, which corresponds to the release of residual water. Moreover, the glass transition temperature $\mathrm{T}_{\mathrm{g}}$ of the cryogels was $354,591,443,389$, and $397^{\circ} \mathrm{C}$ for GelChCS10, GelChCS25, GelChCS50, GelChCS100, and GelChCS250, respectively, as compared to $291{ }^{\circ} \mathrm{C}$ for the control sample. This also demonstrates the formation of more stable structures between the polymer chains in the cryogel network due to the chemical crosslinks in the cryogels.

The MTT assay gives information regarding metabolic activity and proliferative capacity of cells seeded on a scaffold which differ by variated concentrations of chondroitin-6-sulfate (Figure 6). The maximal concentration (100\%) was equal to $1000 \mu \mathrm{g}$ of GelChCS dissolved in $1 \mathrm{~mL}$ of media, sequentially, $50 \%-500 \mu \mathrm{g} / \mathrm{mL}, 25 \%-250 \mathrm{ug} / \mathrm{mL}, 12.25 \%-122.5 \mu \mathrm{g} / \mathrm{mL}$, $6.25 \%-62.5 \mu \mathrm{g} / \mathrm{mL}, 3.1 \%-31.3 \mu \mathrm{g} / \mathrm{mL}, 1.56 \%-15.6 \mu \mathrm{g} / \mathrm{mL}$, and 0.78\%-7.8 $\mu \mathrm{g} / \mathrm{mL}$. According to the obtained data, the cells cultivated in media with the titrated GelChCS50 extract showed a higher ability to proliferate, while for GelChCS250 the same concentrations induce inhibition of cell growth Also, IC50 was determined for each scaffold: GelChCS10-24.11 $\mu \mathrm{g} / \mathrm{mL}$, GelChCS25-88.48 $\mu \mathrm{g} / \mathrm{mL}$, GelChCS50-275.8 $\mu \mathrm{g} / \mathrm{mL}$, GelChCS100-111.7 $\mu \mathrm{g} / \mathrm{mL}$, and GelChCS250-7.257 $\mu \mathrm{g} / \mathrm{mL}$. It can be seen that the GelChCS50 scaffold has the highest maximum permissible concentration and is suitable for cell cultivation. 


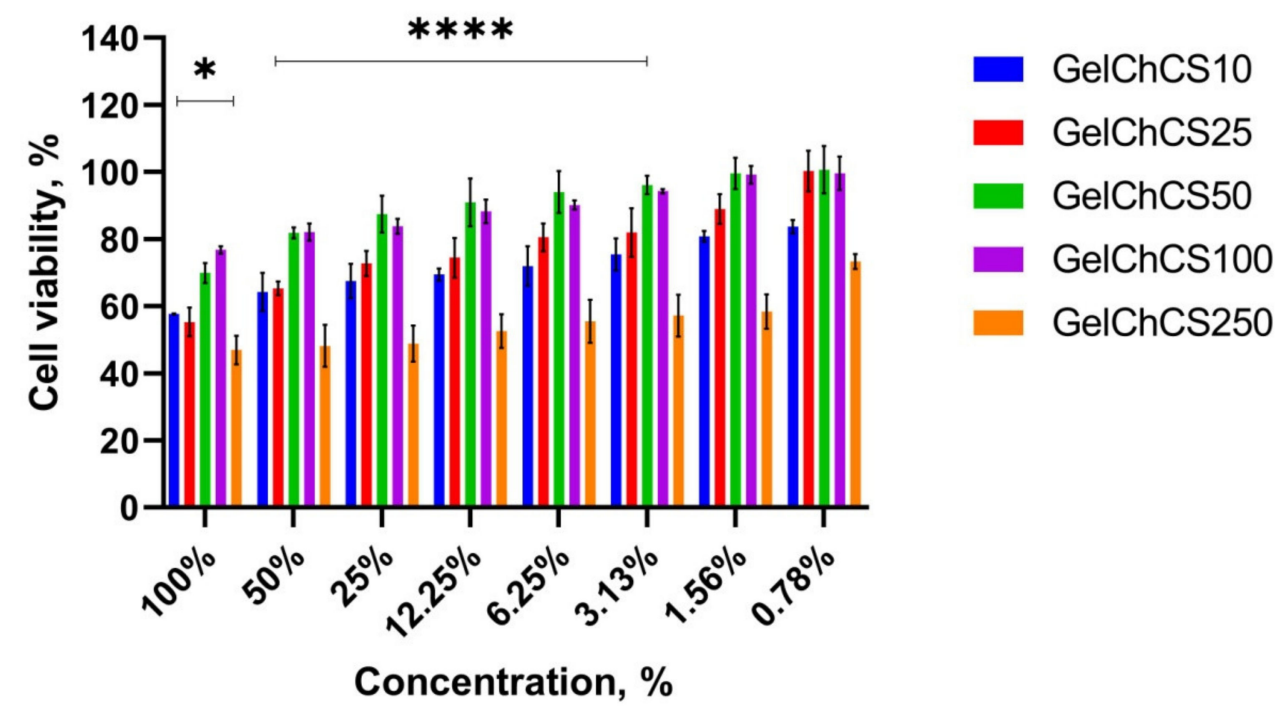

Figure 6. Effects of GelChCS extracts on viability of rat ADMSC presented as percentage of cell viability versus concentration of the extracts. The experiments were repeated in triplicate independently, and the data are expressed as the means $\pm \mathrm{SD}$ with ${ }^{*} p<0.05 ;{ }^{* * *} p<0.0001$.

In order to assess the biocompatibility profiles of cryogels containing different amounts of CS, an MTT assay was conducted using the primary culture of rat ADMSC. Results of the assay showed that the extracts from GelChCS250 exerted high toxic effect on rat ADMSC (Figure 6). The cell viability of rat ADMSC after treatment with GelChCS250 extract (ranging from $1.56 \%$ to $100 \%$ ) was from $58.3 \pm 5.1 \%$ to $46.9 \pm 4.2 \%$, respectively. The extracts from GelChCS10 and GelChCS25 exhibited a weak toxic effect on rat ADMSC and displayed more than 55\% of cell viability after treatment with $100 \%$ extract. The extracts from GelChCS50 and GelChCS100 did not exert toxic effects on the cells and displayed the highest cell viability in comparison to the other GelChCS extracts. The cell viability of rat ADMSC after treatment by $100 \%$ extracts of GelChCS50 and GelChCS100 was $69.9 \pm 2.9 \%$ and $76.7 \pm 1.1 \%$, respectively. Thus, the MTT assay revealed that the cryogels GelChCS50 and GelChCS100 are biocompatible and suitable for further applications in in vivo studies.

\section{Conclusions}

Macroporous cryogels based on gelatin, chitosan, and chondroitin sulfate were synthesized using the cryogelization method $\left(-12{ }^{\circ} \mathrm{C}\right)$ at various CS concentrations using the physical and chemical method of crosslinking. The presence of characteristic functional groups was confirmed by IR spectroscopy. This paper investigated the effect of linear GAG such as CS on the physicochemical properties of Gel/Ch cryogels. As the study has demonstrated, with an increase in the content of chondroitin sulfate, a decrease in porosity was observed and the density of cryogels increased, which led to the formation of a macroporous structure of polymers. The content of the gel fraction for the GelChCS50 cryogel was the highest ( 81\%). The swelling capacities of the cryogels GelChCS10, GelChCS25, and GelChCS50 were the highest; however, the studies on biodegradation showed that the cryogels GelChCS50 and GelChCS100 had the least degree of biodegradation in PBS and retained most of their shape for 8 weeks. SEM studies also revealed the most uniform pore distribution in the GelChCS50 cryogel, which is suitable for cell proliferation. The thermogravimetric analysis showed that when the temperature rose to $800{ }^{\circ} \mathrm{C}$, the weight loss of the crosslinked samples was $80 \%$ on average, while for the non-crosslinked sample it was $95 \%$. The glass transition temperature for the non-crosslinked sample was also lower compared to that of the crosslinked cryogels. An in vitro study of cytotoxicity showed that the synthesized cryogels are not toxic. Since cryogels are composed of natural polymers, it is expected that degradation products will not cause problems with immune rejection during implantation, which in turn makes such materials promising for applications in the 
treatment of bone disease. In the future we plan to use cryogels for preclinical study on the treatment of damaged intervertebral discs, since biopolymers used in our study are the main ECM components of the intervertebral disc.

Supplementary Materials: The following are available online at https: / www.mdpi.com/article/10.3 390/app112110056/s1, Figure S1: SEM images and histogram of pore sizes of the cryogels: (a) GelChCS10, (b) GelChCS25, (c) GelChCS50, (d) GelChCS100, and (e) GelChCS250. Scale bar $=100 \mu \mathrm{m}$.

Author Contributions: Conceptualization, G.K. and V.O.; methodology, G.K., M.Z. and V.O.; software, M.Z.; formal analysis, E.A.M. and A.A.; investigation, G.K. and E.A.M.; writing-original draft preparation, G.K. and M.Z.; writing-review and editing, G.K. and E.A.M.; funding acquisition, G.K. All authors have read and agreed to the published version of the manuscript.

Funding: This research was funded by the Science Committee of the Ministry of Education and Science of the Republic of Kazakhstan (Grant No. AP08052556).

Institutional Review Board Statement: This study was conducted according to the guidelines of the Declaration of Helsinki and approved by the Local Ethics Committee of the National Center for Biotechnology (number NCB-04-2020).

Informed Consent Statement: Not applicable.

Data Availability Statement: All data presented in this paper are available upon request from the corresponding author.

Acknowledgments: The authors thank Oguz Okay (Istanbul Technical University, Turkey) for helpful discussion of the manuscript. The research was financially supported by the Science Committee of the Ministry of Education and Science of the Republic of Kazakhstan (Research program No. OR11465426). Figure 1 and the graphical abstract were created with https:/ / biorender.com/ (accessed on 25 October 2021).

Conflicts of Interest: The authors declare no conflict of interest.

\section{References}

1. Dwivedi, P.; Bhat, S.; Nayak, V.; Kumar, A. Study of Different Delivery Modes of Chondroitin Sulfate Using Microspheres and Cryogel Scaffold for Application in Cartilage Tissue Engineering. Int. J. Polym. Mater. Polym. Biomater. 2014, 63, 859-872. [CrossRef]

2. Kirillova, A.; Yeazel, T.R.; Asheghali, D.; Petersen, S.R.; Dort, S.; Gall, K.; Becker, M.L. Fabrication of Biomedical Scaffolds Using Biodegradable Polymers. Chem. Rev. 2021, 121, 11238-11304. [CrossRef]

3. Ma, P.; Wu, W.; Wei, Y.; Ren, L.; Lin, S.; Wu, J. Biomimetic Gelatin/Chitosan/Polyvinyl Alcohol/Nano-Hydroxyapatite Scaffolds for Bone Tissue Engineering. Mater. Des. 2021, 207, 109865. [CrossRef]

4. Kutlusoy, T.; Oktay, B.; Apohan, N.K.; Süleymanoğlu, M.; Kuruca, S.E. Chitosan-Co-Hyaluronic Acid Porous Cryogels and Their Application in Tissue Engineering. Int. J. Biol. Macromol. 2017, 103, 366-378. [CrossRef] [PubMed]

5. Samrot, A.V.; Sean, T.C.; Kudaiyappan, T.; Bisyarah, U.; Mirarmandi, A.; Faradjeva, E.; Abubakar, A.; Ali, H.H.; Angalene, J.L.A.; Suresh Kumar, S. Production, Characterization and Application of Nanocarriers Made of Polysaccharides, Proteins, Bio-Polyesters and Other Biopolymers: A Review. Int. J. Biol. Macromol. 2020, 165, 3088-3105. [CrossRef] [PubMed]

6. Lozinsky, V.I.; Galaev, I.Y.; Plieva, F.M.; Savina, I.N.; Jungvid, H.; Mattiasson, B. Polymeric Cryogels as Promising Materials of Biotechnological Interest. Trends Biotechnol. 2003, 21, 445-451. [CrossRef] [PubMed]

7. Lozinsky, V.I. Cryostructuring of Polymeric Systems. 50.† Cryogels and Cryotropic Gel-Formation: Terms and Definitions. Gels 2018, 4, 77. [CrossRef]

8. Memic, A.; Colombani, T.; Eggermont, L.J.; Rezaeeyazdi, M.; Steingold, J.; Rogers, Z.J.; Navare, K.J.; Mohammed, H.S.; Bencherif, S.A. Latest Advances in Cryogel Technology for Biomedical Applications. Adv. Ther. 2019, 2, 1800114. [CrossRef]

9. Okay, O.; Lozinsky, V.I. Synthesis and Structure-Property Relationships of Cryogels. In Polymeric Cryogels: Macroporous Gels with Remarkable Properties; Okay, O., Ed.; Advances in Polymer Science; Springer International Publishing: Cham, Switzerland, 2014; pp. 103-157, ISBN 978-3-319-05846-7.

10. Shiekh, P.A.; Andrabi, S.M.; Singh, A.; Majumder, S.; Kumar, A. Designing Cryogels through Cryostructuring of Polymeric Matrices for Biomedical Applications. Eur. Polym. J. 2021, 144, 110234. [CrossRef]

11. Tripathi, A.; Melo, J.S. Cryostructurization of Polymeric Systems for Developing Macroporous Cryogel as a Foundational Framework in Bioengineering Applications. J. Chem. Sci. 2019, 131, 92. [CrossRef]

12. Sultankulov, B.; Berillo, D.; Kauanova, S.; Mikhalovsky, S.; Mikhalovska, L.; Saparov, A. Composite Cryogel with Polyelectrolyte Complexes for Growth Factor Delivery. Pharmaceutics 2019, 11, 650. [CrossRef] 
13. Wang, J.; Yang, H. Superelastic and PH-Responsive Degradable Dendrimer Cryogels Prepared by Cryo-Aza-Michael Addition Reaction. Sci. Rep. 2018, 8, 7155. [CrossRef]

14. Kumar, N.; Desagani, D.; Chandran, G.; Ghosh, N.N.; Karthikeyan, G.; Waigaonkar, S.; Ganguly, A. Biocompatible AgaroseChitosan Coated Silver Nanoparticle Composite for Soft Tissue Engineering Applications. Artif. Cells Nanomed. Biotechnol. 2018, 46, 637-649. [CrossRef] [PubMed]

15. Plieva, F.M.; Savina, I.N.; Deraz, S.; Andersson, J.; Galaev, I.Y.; Mattiasson, B. Characterization of Supermacroporous Monolithic Polyacrylamide Based Matrices Designed for Chromatography of Bioparticles. J. Chromatogr. B 2004, 807, 129-137. [CrossRef] [PubMed]

16. Savina, I.N.; Cnudde, V.; D’Hollander, S.; Hoorebeke, L.V.; Mattiasson, B.; Galaev, I.Y.; Prez, F.D. Cryogels from Poly(2Hydroxyethyl Methacrylate): Macroporous, Interconnected Materials with Potential as Cell Scaffolds. Soft Matter 2007, 3 , 1176-1184. [CrossRef]

17. Ahmed, E.M. Hydrogel: Preparation, Characterization, and Applications: A Review. J. Adv. Res. 2015, 6, 105-121. [CrossRef]

18. Maitra, J.; Shukla, V.K. Cross-Linking in Hydrogels-A Review. Am. J. Polym. Sci. 2014, 4, 25-31.

19. Parhi, R. Cross-Linked Hydrogel for Pharmaceutical Applications: A Review. Adv. Pharm. Bull. 2017, 7, 515-530. [CrossRef] [PubMed]

20. Zhang, Y.; Wang, C.; Jiang, W.; Zuo, W.; Han, G. Influence of Stage Cooling Method on Pore Architecture of Biomimetic Alginate Scaffolds. Sci. Rep. 2017, 7, 16150. [CrossRef]

21. Offeddu, G.S.; Mela, I.; Jeggle, P.; Henderson, R.M.; Smoukov, S.K.; Oyen, M.L. Cartilage-like Electrostatic Stiffening of Responsive Cryogel Scaffolds. Sci. Rep. 2017, 7, 42948. [CrossRef]

22. Hasnain, M.S.; Ahmad, S.A.; Chaudhary, N.; Hoda, M.N.; Nayak, A.K. 1-Biodegradable polymer matrix nanocomposites for bone tissue engineering. In Applications of Nanocomposite Materials in Orthopedics; Inamuddin Asiri, A.M., Mohammad, A., Eds.; Woodhead Publishing Series in Biomaterials; Woodhead Publishing: Sawston, UK, 2019; pp. 1-37. ISBN 978-0-12-813740-6.

23. Bharadwaz, A.; Jayasuriya, A.C. Recent Trends in the Application of Widely Used Natural and Synthetic Polymer Nanocomposites in Bone Tissue Regeneration. Mater. Sci. Eng. C 2020, 110, 110698. [CrossRef]

24. Ponsubha, S.; Jaiswal, A.K. Effect of Interpolymer Complex Formation between Chondroitin Sulfate and Chitosan-Gelatin Hydrogel on Physico-Chemical and Rheological Properties. Carbohydr. Polym. 2020, 238, 116179. [CrossRef]

25. Asghari, F.; Samiei, M.; Adibkia, K.; Akbarzadeh, A.; Davaran, S. Biodegradable and Biocompatible Polymers for Tissue Engineering Application: A Review. Artif. Cells Nanomed. Biotechnol. 2017, 45, 185-192. [CrossRef] [PubMed]

26. Iqbal, N.; Khan, A.S.; Asif, A.; Yar, M.; Haycock, J.W.; Rehman, I.U. Recent Concepts in Biodegradable Polymers for Tissue Engineering Paradigms: A Critical Review. Int. Mater. Rev. 2019, 64, 91-126. [CrossRef]

27. Thönes, S.; Kutz, L.M.; Oehmichen, S.; Becher, J.; Heymann, K.; Saalbach, A.; Knolle, W.; Schnabelrauch, M.; Reichelt, S.; Anderegg, U. New E-Beam-Initiated Hyaluronan Acrylate Cryogels Support Growth and Matrix Deposition by Dermal Fibroblasts. Int. J. Biol. Macromol. 2017, 94, 611-620. [CrossRef] [PubMed]

28. Leandro, A.; Pereira, L.; Gonçalves, A.M.M. Diverse Applications of Marine Macroalgae. Mar. Drugs 2020, 18, 17. [CrossRef]

29. Gómez-Guillén, M.C.; Giménez, B.; López-Caballero, M.E.; Montero, M.P. Functional and Bioactive Properties of Collagen and Gelatin from Alternative Sources: A Review. Food Hydrocoll. 2011, 25, 1813-1827. [CrossRef]

30. Lozinsky, V.I.; Kulakova, V.K.; Ivanov, R.V.; Petrenko, A.Y.; Rogulska, O.Y.; Petrenko, Y.A. Cryostructuring of Polymer Systems. 47. Preparation of Wide Porous Gelatin-Based Cryostructurates in Sterilizing Organic Media and Assessment of the Suitability of Thus Formed Matrices as Spongy Scaffolds for 3D Cell Culturing. E-Polym. 2018, 18, 175-186. [CrossRef]

31. Hoque, M.E.; Nuge, T.; Tshai, K.Y.; Nordin, N.; Prasad, V. Gelatin Based Scaffolds For Tissue Engineering-A Review. Polym. Res. J. 2015, 9, 15-32.

32. Boonlertnirun, S.; Boonraung, C.; Suvanasara, R. Application of Chitosan in Rice Production. J. Met. Mater. Miner. 2008, 18, 47-52.

33. Kurakula, M.; Naveen, N.R. Prospection of Recent Chitosan Biomedical Trends: Evidence from Patent Analysis (2009-2020). Int. J. Biol. Macromol. 2020, 165, 1924-1938. [CrossRef] [PubMed]

34. Dickinson, L.E.; Gerecht, S. Engineered Biopolymeric Scaffolds for Chronic Wound Healing. Front. Physiol. 2016, 7, 341. [CrossRef] [PubMed]

35. Bang, S.; Jung, U.-W.; Noh, I. Synthesis and Biocompatibility Characterizations of in Situ Chondroitin Sulfate-Gelatin Hydrogel for Tissue Engineering. Tissue Eng. Regen. Med. 2018, 15, 25-35. [CrossRef] [PubMed]

36. Wartenberg, A.; Weisser, J.; Schnabelrauch, M. Glycosaminoglycan-Based Cryogels as Scaffolds for Cell Cultivation and Tissue Regeneration. Molecules 2021, 26, 5597. [CrossRef]

37. Kai, Y.; Yoneyama, H.; Yoshikawa, M.; Kimura, H.; Muro, S. Chondroitin Sulfate in Tissue Remodeling: Therapeutic Implications for Pulmonary Fibrosis. Respir. Investig. 2021, 59, 576-588. [CrossRef] [PubMed]

38. Esko, J.D.; Kimata, K.; Lindahl, U. Proteoglycans and Sulfated Glycosaminoglycans. In Essentials of Glycobiology; Varki, A., Cummings, R.D., Esko, J.D., Freeze, H.H., Stanley, P., Bertozzi, C.R., Hart, G.W., Etzler, M.E., Eds.; Cold Spring Harbor Laboratory Press: Cold Spring Harbor, NY, USA, 2009; ISBN 978-0-87969-770-9.

39. Chen, S.; Chen, W.; Chen, Y.; Mo, X.; Fan, C. Chondroitin Sulfate Modified 3D Porous Electrospun Nanofiber Scaffolds Promote Cartilage Regeneration. Mater. Sci. Eng. C 2021, 118, 111312. [CrossRef]

40. Kuo, C.-Y.; Chen, C.-H.; Hsiao, C.-Y.; Chen, J.-P. Incorporation of Chitosan in Biomimetic Gelatin/Chondroitin-6Sulfate/Hyaluronan Cryogel for Cartilage Tissue Engineering. Carbohydr. Polym. 2015, 117, 722-730. [CrossRef] [PubMed] 
41. Chang, C.-H.; Liu, H.-C.; Lin, C.-C.; Chou, C.-H.; Lin, F.-H. Gelatin-Chondroitin-Hyaluronan Tri-Copolymer Scaffold for Cartilage Tissue Engineering. Biomaterials 2003, 24, 4853-4858. [CrossRef]

42. Chen, C.-H.; Kuo, C.-Y.; Chen, J.-P. Effect of Cyclic Dynamic Compressive Loading on Chondrocytes and Adipose-Derived Stem Cells Co-Cultured in Highly Elastic Cryogel Scaffolds. Int. J. Mol. Sci. 2018, 19, 370. [CrossRef] [PubMed]

43. Savina, I.N.; Zoughaib, M.; Yergeshov, A.A. Design and Assessment of Biodegradable Macroporous Cryogels as Advanced Tissue Engineering and Drug Carrying Materials. Gels 2021, 7, 79. [CrossRef]

44. Saylan, Y.; Denizli, A. Supermacroporous Composite Cryogels in Biomedical Applications. Gels 2019, 5, 20. [CrossRef]

45. He, Y.; Wang, C.; Wang, C.; Xiao, Y.; Lin, W. An Overview on Collagen and Gelatin-Based Cryogels: Fabrication, Classification, Properties and Biomedical Applications. Polymers 2021, 13, 2299. [CrossRef] [PubMed]

46. Caló, E.; Barros, J.; Ballamy, L.; Khutoryanskiy, V. Poly(Vinyl Alcohol)-Gantrez ${ }^{\circledR}$ AN Cryogels for Wound Care Applications. RSC Adv. 2016, 6, 105487-105494. [CrossRef]

47. Nieto-Suárez, M.; López-Quintela, M.A.; Lazzari, M. Preparation and Characterization of Crosslinked Chitosan/Gelatin Scaffolds by Ice Segregation Induced Self-Assembly. Carbohydr. Polym. 2016, 141, 175-183. [CrossRef] [PubMed]

48. Verma, V.; Verma, P.; Kar, S.; Ray, P.; Ray, A.R. Fabrication of Agar-Gelatin Hybrid Scaffolds Using a Novel Entrapment Method for in Vitro Tissue Engineering Applications. Biotechnol. Bioeng. 2007, 96, 392-400. [CrossRef]

49. Kathuria, N.; Tripathi, A.; Kar, K.K.; Kumar, A. Synthesis and Characterization of Elastic and Macroporous Chitosan-Gelatin Cryogels for Tissue Engineering. Acta Biomater. 2009, 5, 406-418. [CrossRef] [PubMed]

50. Tripathi, A.; Vishnoi, T.; Singh, D.; Kumar, A. Modulated Crosslinking of Macroporous Polymeric Cryogel Affects In Vitro Cell Adhesion and Growth. Macromol. Biosci. 2013, 13, 838-850. [CrossRef] [PubMed]

51. Plieva, F.M.; Karlsson, M.; Aguilar, M.-R.; Gomez, D.; Mikhalovsky, S.; Galaev', I.Y. Pore Structure in Supermacroporous Polyacrylamide Based Cryogels. Soft Matter 2005, 1, 303-309. [CrossRef] [PubMed]

52. Rinaudo, M. Chitin and Chitosan: Properties and Applications. Prog. Polym. Sci. 2006, 31, 603-632. [CrossRef]

53. Pacelli, S.; Di Muzio, L.; Paolicelli, P.; Fortunati, V.; Petralito, S.; Trilli, J.; Casadei, M.A. Dextran-Polyethylene Glycol Cryogels as Spongy Scaffolds for Drug Delivery. Int. J. Biol. Macromol. 2021, 166, 1292-1300. [CrossRef] [PubMed]

54. Lee, J.W.; Ahn, G.; Kim, J.Y.; Cho, D.-W. Evaluating Cell Proliferation Based on Internal Pore Size and 3D Scaffold Architecture Fabricated Using Solid Freeform Fabrication Technology. J. Mater. Sci. Mater. Med. 2010, 21, 3195-3205. [CrossRef] [PubMed]

55. Perez, R.A.; Mestres, G. Role of Pore Size and Morphology in Musculo-Skeletal Tissue Regeneration. Mater. Sci. Eng. C Mater. Biol. Appl. 2016, 61, 922-939. [CrossRef] [PubMed] 